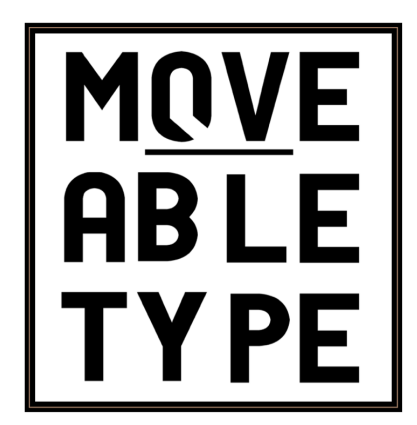

'Ambient Avant-Gardes in Sophie Sieta's Provisional Avant-Gardes

Author: Zoe Rucker

Source: Moveable Type, Vol.13, 'Ambience' (2021)

DOI: $10.14324 / 111.1755-4527.115$

MoveableType is a Graduate, Peer-Reviewed Journal based in the Department of English at UCL.

(C) 2021 Zoe Rucker. This is an Open Access article distributed under the terms of the Creative Commons Attribution License (CC-BY) 4.ohttps://creativecommons.org/licenses/by/4.0/, which permits unrestricted use, distribution, and reproduction in any medium, provided the original author and source are credited. 


\title{
Ambient Avant-Gardes in Sophie Sieta's Provisional Avant-Gardes
}

\author{
Zoe Rucker
}

\begin{abstract}
Provisional Avant-Gardes: Little Magazine Communities from Dada to Digital. By Sophie Sieta. 2019. Pp. xii + 272. £23.99. Stanford University Press.
\end{abstract}

ISBN 9781503609587

Sophie Sieta has filled an important gap in scholarship surrounding both theories of the avant-garde and material textual studies with her first monograph, Provisional Avant-Gardes (2019). From 'Dada to Digital', Sieta navigates a 'diachronic' investigation of the relationship between avant-garde literary communities and the print formats in which they have often published their work. In doing so, she expands the historical range within which considerations of the avant-garde and little magazines are usually framed (the Oxford Critical and Cultural History of Modernist Magazines ends in the 1960s) and intersects both areas of study with the digital turn. Sieta thus offers a fascinating and dynamic discussion of the relationship between expressive, formal innovation and the material text, which illuminates this issue's theme of 'ambience'. Rigorously engaging with the entanglement and the permeability of boundaries between text, form, and self-definition, this study places increasingly ripe and timely elements of ambient literature towards the forefront of modern and contemporary literary studies' concerns.

Sieta's monograph incisively illustrates how the periodical print format has been, and still is, closely tied to avant-garde communities' self-definitions and is, therefore, integral to the development of the styles and forms associated with the avant-garde itself. One of the book's most innovative contributions is, as the title suggests, its reconceptualisation of theories of the avant-garde around ideas of 'provisionality' and what Sieta calls 'proto-form', a term used to describe 'the avant-garde communities that form in and around magazines'. Rather than taking the avant-garde movements she examines in each chapter as cohesive

\footnotetext{
${ }^{1}$ Sophie Sieta, Provisional Avant-Gardes: Little Magazine Communities from Dada to Digital (Stanford: Stanford University Press, 2019), p. 3. Subsequent quotations will be cited parenthetically in the text.
} 
communities, each avant-garde print community is approached as a 'discursive and malleable construct' that utilises their particular print medium as a means of negotiating aesthetic, political, social, and gender-related issues (16). In this way, we begin to view these little magazines as forums for the rehearsal of heterogeneous and eclectic ideas rather than as the mediums for decisive editorial manifestos.

The book's five chapters examine a wide but discriminating range of little magazines, avant-garde coteries, and authors, chosen to support the narrative of the ongoing invention and reinvention they constitute when linked together. Each new chapter challenges our understanding of the term 'avant-garde', showing its previous use to be too imprecise and too narrow because of the inherent 'provisionality' that distinguish qualities which become initially labelled as avant-garde. Sieta's analytical approach, drawing on close readings, commentaries on visual art, diaries and letters, politics of inclusion, and a keen awareness of the text as material object, is pertinent and insightful. In this regard, her approach is extremely conducive to highlighting the ambient qualities inherent to both print and digital periodical publications. In particular, Sieta does an excellent job of drawing attention to the relationships between the 'provisional' materiality of these 'texts' - the very sense of the publication as a material object with its various innovative formal linguistic and visual qualities - and the 'provisional', fluid identity of the communities that publish them. Thus, based on Sieta's conclusions, it is fair to say that these ambient publications are created by ambient groups of artists and writers.

Modernist scholars will be particularly intrigued by Sieta's first chapter, 'The Magazine as Laboratory in New York Proto-Dada Communities' as a new approach to a period of little magazine production that has already been well documented and critically treated by scholars of 'the modernist little magazine'. Sieta argues that in considering avant-garde magazines within a framework in which they must, as Ezra Pound argued, 'know what [they] think or where [they] are going.' ${ }^{2}$ As Sieta argues, 'magazines and groups that lacked programs have either been excluded from histories of the avant-garde or have been

\footnotetext{
${ }^{2}$ Ezra Pound, 'Small Magazines' as quoted by Sieta, p. 19.
} 
discussed within a framework that simply does not apply to those communities' (19). Focusing on magazines such as 291, The Blind Man, Others, and the Little Review, as 'proto-Dada' publications, Sieta outlines a network of 'practitioners' whose work sometimes flirted with more canonical features of Dada but did not always announce itself as such. From this, she builds her metaphor of the little magazine as a 'laboratory' for ideas, typography, designs, and forms. However, her analysis of examples, such as Duchamp's Fountain in Blind Man (1917), to illustrate this read somewhat briskly. Nonetheless, her discussion of magazine editorships self-fashioning their publications through inclusion politics, editorials, and reviews which 'reinforce the image they want to project' opens a discussion of the extent to which little magazines can/should be seen as instruments for editors to expound their ideals or as mediums for discourse, debate, and experimentation (47). These issues are well-trodden by periodical studies experts, yet Sieta refreshes this debate with real purpose to her discussion, using it to highlight the quality of 'provisionality' she argues for.

Sieta embarks on comparatively newer territory in the book's following chapters, which consider avant-garde little magazine groups after the modernist era. The fourth chapter on 'Feminist Avant-Garde Magazines', which explores publications such as Raddle Moon, $M / E / A / N / I / N / G, H O W($ ever), HOW2, and Chain, is particularly fruitful in its exploration of the relationship between the development of second-wave and early third-wave feminist group identities and the opportunities for experimenting with self-expression through the magazine form. Sieta's continual references to how these later magazines continued to draw formal inspiration from modernist little magazines reinforces the diachronic nature of her study and encourages extended discussions of the wider dissemination and derivates of modernist legacies.

In the final chapter, 'Print Communities in the Digital Age', Sieta again endeavours to foster a sense of continuity, assuring the reader that the advent of the digital age does not mean the death of print for the avant-garde. She posits the term 'intermediation' as a way of describing 'the ongoing coexistence and mutual transformation of print and digital 
technologies' (163). While she does discuss new opportunities for experimentation that come with publication via the print medium, such as being able to place different file formats alongside each other - a PDF which includes a .jpg, an .mp3, and a link to a YouTube video, for example - she also explores publications which have tried to recreate the materiality of print using the digital medium. The chapter concludes by figuring the future of the avant-garde little magazine as a 'vivarium', out of which one can watch 'a small ecosystem as it takes place', which stands as an excellent metaphor for capturing the essentially porous, ambient relationship between little magazines and the communities and coteries they stem from, and echo back into the waves of their avant-garde experimentation (188).

Provisional Avant-Gardes, thus, stands as an important contribution to broaden the horizons of studies of little magazines and to redefine ideas of 'the avant-garde', while also opening up avenues for probing discussions of ambient literature, such as the relationships between text, materiality, and community. Overall, the prose is well-written and the book's central argument innovative and, for the most part, well illustrated through varied examples. While Field points out that Sieta's book might have done well in asking 'whether a new term might be needed in light of how [the concept of the] "avant-garde" is bowed down with historical meaning and misunderstanding', I believe that the fact that she does not supports her aim of showing how diversely and 'provisionally' the term has been used over time. ${ }^{3}$ Either way, revisiting these semantics and this debate might be an avenue for further research.

\footnotetext{
${ }^{3}$ Douglas Field, 'From Laboratory to Vivarium', Review 31, (16 April 2020)

<http://review31.co.uk/article/view/68o/from-laboratory-to-vivarium>.
} 